\title{
Procalcitonin kinetics as a prognostic marker in severe sepsis/septic shock
}

\author{
Banani Poddar, Mohan Gurjar, Sushma Singh', Amita Aggarwal', Ratender Singh, Afzal Azim, \\ Arvind Baronia
}

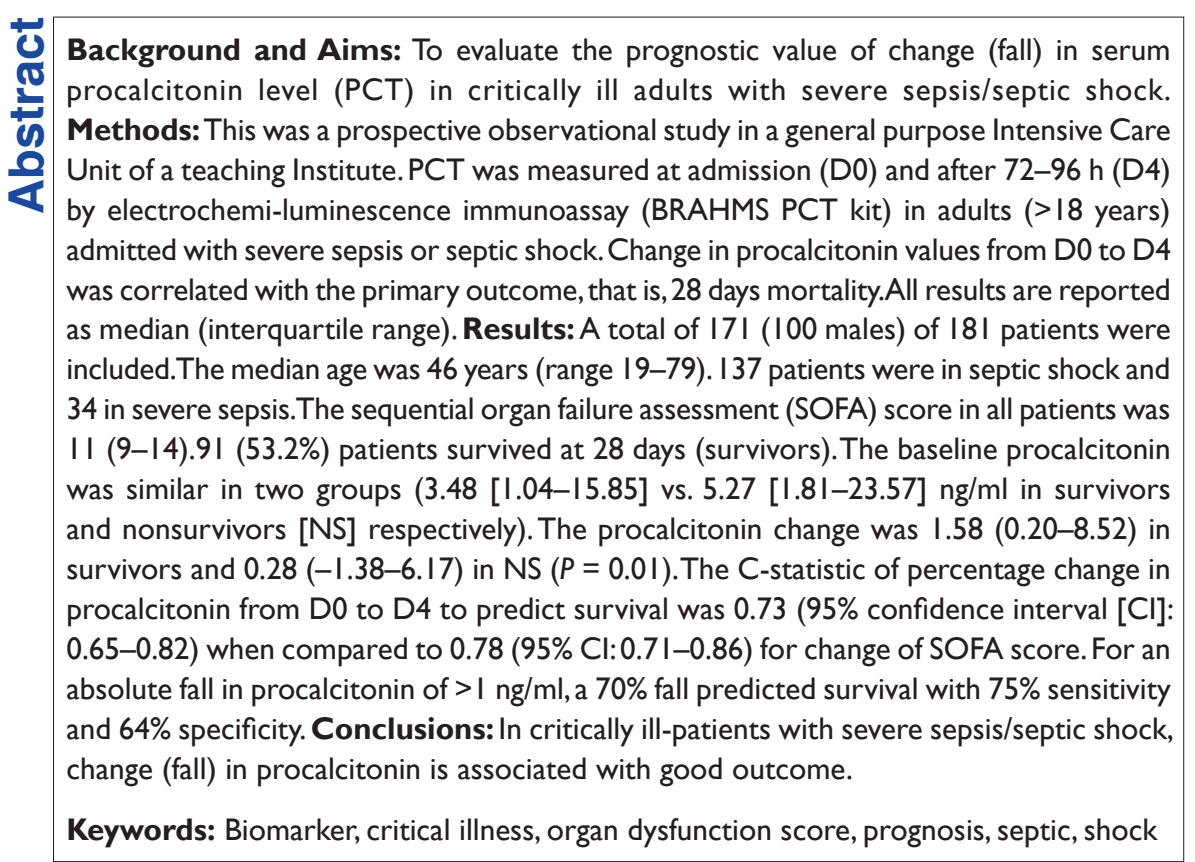

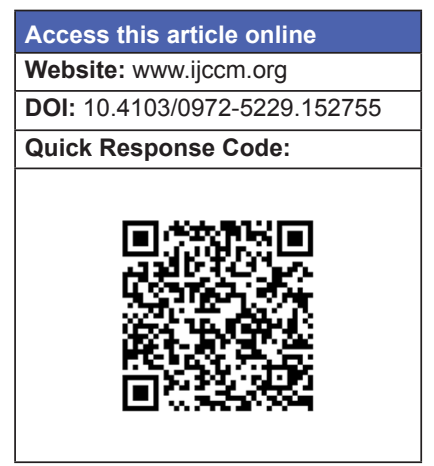

\section{Introduction}

Sepsis is one of the important reasons for Intensive Care Unit (ICU) admission and carries a high morbidity and mortality. To be able to quickly identify the prognosis of sepsis is of vital importance to allocate appropriate resources. ${ }^{[1]}$ Several biomarkers have been studied in this regard; of them, procalcitonin seems promising. Procalcitonin, a precursor of the thyroid hormone calcitonin, remains very low in physiological conditions (level $<0.1 \mathrm{ng} / \mathrm{ml}$ ). Following systemic

\section{From:}

Departments of Critical Care Medicine and ${ }^{1}$ Clinical Immunology, Sanjay

Gandhi Postgraduate Institute of Medical Sciences, Lucknow, Uttar Pradesh,

India

\section{Correspondence:}

Dr. Banani Poddar, Department of Critical Care Medicine, Sanjay

Gandhi Postgraduate Institute of Medical Sciences, Lucknow - 226014 ,

Uttar Pradesh, India. E-mail: bananip @ hotmail.com bacterial infections, the level rises rapidly and peaks by 6-12 $\mathrm{h}$ after the onset of infection; and falls with a control in the infection.

Procalcitonin in sepsis has been studied in various different roles. It was considered a novel biomarker that could differentiate between infectious and noninfectious causes (sepsis vs. systemic inflammatory response syndrome [SIRS]) in critically ill patients; however, this is not supported by the current literature. ${ }^{[2,3]}$ Neverthless, it continues to find utility in guiding the duration of antibiotics $;^{[1,4,5]}$ procalcitonin guidance significantly reduced antibiotic duration without increasing infection relapse or mortality. ${ }^{[6]}$ Procalcitonin levels have been found to be higher in patients with more serious illnesses; hence it was believed that this can be used to assess the prognosis. ${ }^{[7,8]}$ When this was attempted in critically ill patients, however, no correlation was found. ${ }^{[1]}$ Rather, it 
was found that a change in procalcitonin level correlates better with prognosis.

Available literature on change in procalcitonin level as a prognostic marker in critically ill patients is on small groups of patients with specific illnesses (ventilator-associated pneumonia [VAP], postoperative sepsis, etc.). In these studies, the number of patients with severe sepsis or septic shock is even smaller. Hence, we planned to evaluate the prognostic value of change (or fall) in procalcitonin level in a group of critically ill patients with severe sepsis/septic shock.

\section{Methods}

Consecutive adults (age $>18$ years) with severe sepsis/ septic shock on admission to the general ICU of a tertiary care teaching hospital were prospectively included. Severe sepsis was defined as the presence of sepsis (2 or more SIRS criteria associated with suspected or proven infection) along with organ dysfunction, hypoperfusion or hypotension. ${ }^{[9]}$ Septic shock was defined as sepsis-induced hypotension despite fluid resuscitation along with evidence of hypoperfusion. Patients on immunosuppressive therapy and those in the terminal stage of any chronic disease (e.g., cirrhosis Child C) were excluded.

After obtaining written informed consent from the close relatives, two $\mathrm{ml}$ of blood was collected from the patient soon after admission (D0); and a repeat sample was obtained after 72-96 h (D4). Serum was separated and stored at $-80^{\circ} \mathrm{C}$ for further analysis. The study was approved by the Institutional Ethics committee.

All patients were managed as per the decision of the treating physician. Data collected included demographic and clinical characteristics of the patients, relevant laboratory results and cultures, and details of therapy. ICU prognostication scores, that is, acute physiology and chronic health evaluation II (APACHE II) and sequential organ failure assessment (SOFA) scores were calculated in all patients and recorded. The patients were followed-up till 28 days and the outcome at 28 days was noted as the primary outcome.

Procalcitonin estimation in the serum was done using the commercially available electrochemiluminescence immunoassay (BRAHMS PCT kit) using a Cobase 411 analyzer with a sensitivity of $<0.02 \mathrm{ng} / \mathrm{ml}$ and a measuring range of $0.02-100 \mathrm{ng} / \mathrm{ml}$. Values above $100 \mathrm{ng} / \mathrm{ml}$ were not delineated further and reported as such. All such values were taken as $100 \mathrm{ng} / \mathrm{ml}$ for the purpose of calculations.

\section{Statistical analysis}

Statistical analysis was done using the statistical software SPSS 16 (IBM Corporation, USA). Those who survived till 28 days after study enrolment were considered as "survivors." Intergroup comparisons were done using nonparametric tests. Receiver operating characteristic (ROC) curves were constructed to identify the most discriminatory values of change in procalcitonin level and SOFA score. Significance level was considered at $P<0.05$.

\section{Results}

A total of 542 patients were admitted to the ICU between March 2011 and June 2013; 181 of these with severe sepsis/septic shock fulfilled the inclusion criteria. Of these, four patients refused consent while in six patient's treatment was either withheld/withdrawn. Hence, samples of 171 patients were analyzed. Of these, a second sample could be taken on D4 in 139 patients as some patients died before the second sample could be taken while some samples clotted and some patients were missed.

The median age of the patients was 46 years (range 19-79 years, interquartile range [IQR] 30-58). The baseline characteristics of the patients are as shown in Table 1.

Among the patients included in the study, 80 died at the end of 28 days; thus 91 patients were survivors (S) and 80 nonsurvivors (NS). The severity of illness of the patients at study entry and their outcome is as shown in Table 2.

All patients required organ support in the ICU; $160(94.1 \%)$ required mechanical ventilation, 154 (91.7\%) required vasoactive drugs, $84(49.1 \%)$ required renal replacement therapy (at least one session) and $130(76.02 \%)$ required transfusion of any blood product. At 28 days, the median days of mechanical ventilation was 8 (IQR 4-15 days), vasoactive drug infusions were 5 (IQR 3-10 days) and antibiotics was 16 (IQR $8-24)$. A median of 0 renal replacement therapies was used (IQR 0-4). Regarding blood product transfusions, $113(66.1 \%)$ patients required packed red blood cell transfusions with a median of 2 units (IQR 0-4 units); 91 (53.2) required fresh frozen plasma transfusions with a median of 2 units (IQR 0-6) and 59 (34.5\%) required RDP transfusions with a median of 0 units (IQR 0-5). More NS required transfusions as compared to survivors (70/80, $87.5 \%$ vs. $60 / 91,65.9 \% P=0.001)$.

Among the baseline characteristics of the patients, age, gender, admission type (medical, surgical or 
obstetric), primary diagnosis, patient location prior to ICU admission and presence or absence of comorbidities did not affect outcome. On the other hand, NS had more nosocomial infections as compared to community acquired infections (38/80 in NS vs. 26/91 in S; $P=0.012)$, were in septic shock more often as compared to severe sepsis (76/80 in NS vs. 61/91 in S; $P<0.01)$ and had a higher number of organ systems involved (median 4 in NS vs. 3 in $S ; P<0.01)$. Gram-negative infections were predominant in both survivors and NS.

Regarding the severity of illness, APACHE II and SOFA scores were compared in the two groups. Both scores were higher in the NS [Table 2]. Parameters used to identify

\begin{tabular}{|c|c|}
\hline Characteristic & Number (\%) \\
\hline Male:female & 100:7I \\
\hline \multicolumn{2}{|l|}{ Admission type } \\
\hline Medical & $149(87.1)$ \\
\hline Surgical & $12(7.2)$ \\
\hline Obstetric & $10(5.8)$ \\
\hline \multicolumn{2}{|c|}{ Patient location prior to ICU admission } \\
\hline Emergency & $47(27.5)$ \\
\hline Any ward & $32(18.7)$ \\
\hline Another ICU & $92(53.8)$ \\
\hline \multicolumn{2}{|l|}{ Type of sepsis } \\
\hline Community acquired & $107(62.6)$ \\
\hline Nosocomial & $64(37.4)$ \\
\hline \multicolumn{2}{|l|}{ Diagnostic category } \\
\hline Pneumonia & $47(27.5)$ \\
\hline Pancreatitis & $27(15.8)$ \\
\hline Tropical infections & $26(15.2)$ \\
\hline Other $\mathrm{Gl}$ conditions & $21(12.3)$ \\
\hline Urinary tract infections & $13(7.6)$ \\
\hline Miscellaneous & $37(2 \mathrm{l} .6)$ \\
\hline \multicolumn{2}{|l|}{ Organ systems involved } \\
\hline Respiratory & $155(90.6)$ \\
\hline Cardiovascular & $|3|(76.6)$ \\
\hline Renal & $110(64.3)$ \\
\hline Hematological & $58(33.9)$ \\
\hline Neurological & $37(2 \mathrm{l} .6)$ \\
\hline Gl including hepatic & $36(2 \mathrm{I} .1)$ \\
\hline Endocrine/metabolic & $10(5.8)$ \\
\hline \multicolumn{2}{|l|}{ Comorbidities } \\
\hline Diabetes & $36(2 I . I)$ \\
\hline Hypertension & $40(23.4)$ \\
\hline Hypothyroidism & $15(8.8)$ \\
\hline Cardiac conditions & $16(9.4)$ \\
\hline Respiratory conditions & $19(11.1)$ \\
\hline Hepatobiliary diseases & $9(5.3)$ \\
\hline Obesity & $06(3.5)$ \\
\hline Others & $10(5.8)$ \\
\hline None & $80(46.8)$ \\
\hline \multicolumn{2}{|l|}{ Microbiologic data } \\
\hline Gram-negative & $65(38)$ \\
\hline Gram-positive & $6(3.5)$ \\
\hline Mixed bacterial & $10(5.8)$ \\
\hline Fungal & $10(5.8)$ \\
\hline Vector borne & $9(5.3)$ \\
\hline Possible colonizations & $14(8.2)$ \\
\hline All tests negative & $57(33.3)$ \\
\hline
\end{tabular}

ICU: Intensive Care Unit; GI: Gastrointestinal sepsis, that is, total leukocyte count and temperature, were similar in both groups as were the perfusion parameters, central venous oxygen saturation and base excess. The global perfusion parameter, lactate, however, was higher in NS as compared to survivors (median value $2.0 \mathrm{mmol} / \mathrm{L}$ in NS vs. $1.5 \mathrm{mmol} / \mathrm{L}$ in $\mathrm{S}, P=0.02)$.

Median procalcitonin level in the entire group of patients at study entry was $3.83 \mathrm{ng} / \mathrm{ml}$ (IQR 1.24-29.17); it was $3.48 \mathrm{ng} / \mathrm{ml}$ (IQR 1.04-15.85) in survivors as against 5.27 (IQR 1.81-23.57) in NS $(P=0.14)$. Procalcitonin level decreased to a median of $1.48 \mathrm{ng} / \mathrm{ml}$ (IQR $0.66-11.08$ ) on D4 with values of $0.98 \mathrm{ng} / \mathrm{ml}$ and $6.09 \mathrm{ng} / \mathrm{ml}$ in survivors and NS respectively $(P<0.01)$. The procalcitonin level in the patients with different diagnostic categories was similar (data not shown).

Comparison of the change in procalcitonin levels in survivors and NS is shown in Table 3 along with the change in values of SOFA score, lactate levels, central venous oxygen saturation, $\mathrm{pH}$ and base excess over the same period (i.e, 72-96 h). Change in procalcitonin level and SOFA score are significant while the rest are not significant. Change in procalcitonin level in survivors from D0 to D4 $(3.48 \mathrm{ng} / \mathrm{ml}$ to $0.98 \mathrm{ng} / \mathrm{ml})$ is significant while there is no change in NS $(5.27 \mathrm{ng} / \mathrm{ml}$ to $6.09 \mathrm{ng} / \mathrm{ml})$.

To better quantify the fall in procalcitonin levels, we looked at the percentage change in the procalcitonin value from the baseline value as a prognostic marker. Overall, the procalcitonin value decreased by a median of $59.7 \%$ in the entire group (IQR 2.9-79.0\%). The median value in survivors and NS was 73.5\% (IQR 35-85) and 24.4\% (IQR -40.3-63.9); this difference was statistically significant $(P<0.01)$. This is depicted graphically in the box plot at Figure 1.

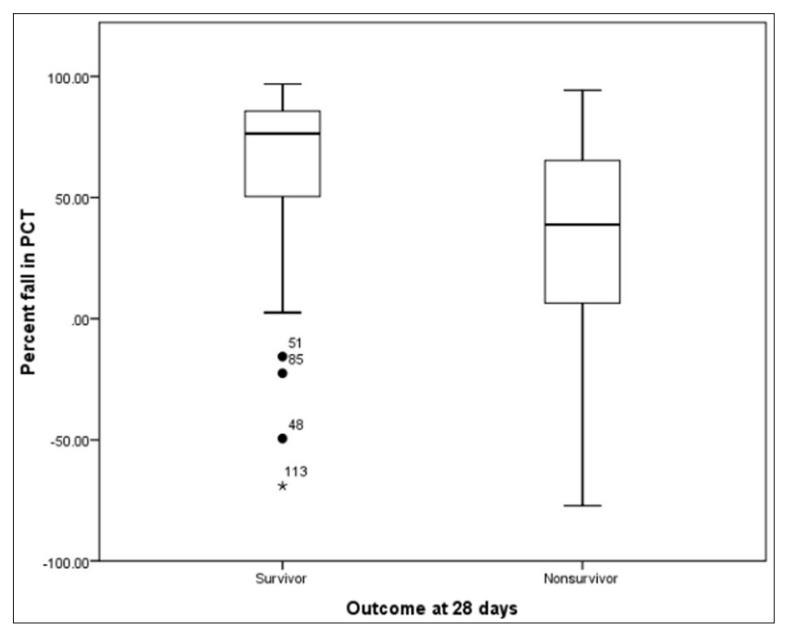

Figure I: Percentage fall in procalcitonin levels in survivors and nonsurvivors 


\section{Table 2: Severity of illness at study entry and 28-day outcome}

\begin{tabular}{|c|c|c|c|}
\hline Characteristic & All patients $(n=\mid 7 I)$ & Survivors $(n=91)$ & Nonsurvivors $(n=80)$ \\
\hline \multicolumn{4}{|l|}{ Severity of sepsis* } \\
\hline Severe sepsis & 34 & 30 & 4 \\
\hline Septic shock & 137 & 61 & 76 \\
\hline Length of ICU stay* (days) & $12(8-23)$ & $19(10-33)$ & $9(4-14)$ \\
\hline Length of hospital stay* (days) & $16(9-28.5)$ & $23.5(13-44.5)$ & II (5-17) \\
\hline APACHE II score* & $18(|5-2|)$ & $16(12-21)$ & $19(17-22.3)$ \\
\hline SOFA score* & $11(9-14)$ & $10(8-13)$ & $13(11-15)$ \\
\hline Total leucocyte count $(\times 1000 / \mathrm{cmm})$ & $16.6(11.7-23.5)$ & $15.8(11.7-23.4)$ & $16.7(\mid \mathrm{I}-24.0)$ \\
\hline Lactate $(\mathrm{mmol} / \mathrm{L})^{*}$ & $1.8(1.2-2.6)$ & $1.5(I . I-2.2)$ & $2.0(1.4-3.1)$ \\
\hline $\mathrm{ScvO}_{2}(\%)$ & $72(67-79)$ & $73(68-80)$ & $72(65-78)$ \\
\hline Base excess & $-5.7(-8.4--1.5)$ & $-5.5(-8.2--0.5)$ & $-6.0(-9.2--2.2)$ \\
\hline $\mathrm{pH}$ & $7.31(7.25-7.37)$ & $7.33(7.27-7.38)$ & $7.30(7.22--7.36)$ \\
\hline Procalcitonin D0 (ng/ml) & $3.83(1.24-21.17)$ & $3.48(1.04-15.85)$ & $5.27(I .8 I-23.57)$ \\
\hline Procalcitonin D4* (ng/ml) & I. $48(0.66-11.08)$ & $0.98(0.44-4.64)$ & $6.09(1.03-18.75)$ \\
\hline
\end{tabular}

Table 3: Median (IQR) change (day 0 minus day 4) in different parameters

\begin{tabular}{|c|c|c|c|}
\hline Parameter & All patients $(n=|7|)$ & Survivors $(n=91)$ & Nonsurvivors $(n=80)$ \\
\hline Procalcitonin* & $1.18(0.02-7.86)$ & $1.58(0.20-8.52)$ & $0.28(-1.38-6.17)$ \\
\hline SOFA score* & $2(0-4)$ & $3(I-5)$ & $0(-1-2)$ \\
\hline Lactate $(\mathrm{mmol} / \mathrm{L})$ & $0.2(-0.4-0.8)$ & $0.2(-0.4-0.8)$ & $0.2(-0.3-0.9)$ \\
\hline $\mathrm{ScvO}_{2}$ as $\%$ & $0(-7-6)$ & $I(-5 . I-6.6)$ & $-2.0(-9-5.3)$ \\
\hline Base excess & $-1.6(-7.8-0.2)$ & $-1.9(-8.2--0.1)$ & $-1.2(-6.8-0.9)$ \\
\hline $\mathrm{pH}$ & $-0.03(-0.1 \mathrm{I}-0.0 \mathrm{I})$ & $-0.03(-0.12-0.0)$ & $-0.03(-0.08-0.02)$ \\
\hline
\end{tabular}

Comparison between survivors and nonsurvivors $* P<0.05$. SOFA: Sequential organ failure assessment; IQR: Interquartile range; $\mathrm{ScvO}_{2}$ : Central venous oxygen saturation

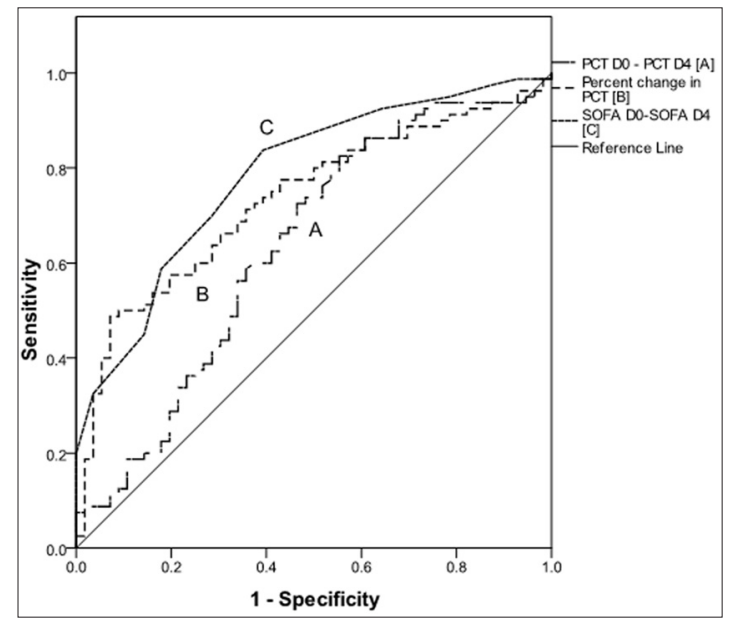

Figure 2: Receiver operating characteristic curves of change in procalcitonin level (PCT D0-PCT D4), sequential organ failure assessment score (SOFA D0-SOFA D4) and percentage change in procalcitonin level (percent change in PCT)

Receiver operating characteristic curves were constructed to identify the most discriminatory values of change in procalcitonin and change in SOFA score [Figure 2]. The area under the curve (AUC) for change in PCT to predict survival was 0.64 (95\% confidence interval $[\mathrm{CI}]: 0.54-0.73 ; P=0.007)$ as compared to 0.78 (95\% CI: $0.71-0.86 ; P<0.01$ ) for change in SOFA score. Percentage change in PCT gives a C-statistic of 0.73 (95\% CI: $0.65-0.82 ; P<0.01) .50 \%$ and
$75 \%$ fall in PCT value yielded $68 \%$ and $47 \%$ sensitivity and $64 \%$ and $93 \%$ specificity respectively to predict survival at 28 days. Among those patients in whom the absolute fall in procalcitonin was $>1 \mathrm{ng} / \mathrm{ml}$, a $70 \%$ fall in procalcitonin predicted survival with $75 \%$ sensitivity and $64 \%$ specificity.

In 28 patients, the procalcitonin level remained $\leq 1 \mathrm{ng} / \mathrm{ml}$ on D0 and D4. When the analysis was repeated excluding these patients, the median procalcitonin level on D0 was $6.99 \mathrm{ng} / \mathrm{ml}$ (IQR 2.17-37.67) and $3.80 \mathrm{ng} / \mathrm{ml}$ (IQR 1.01-14.79) on $\mathrm{D} 4$. The corresponding values in survivors and NS were $7.07 \mathrm{ng} / \mathrm{ml}$ and $6.82 \mathrm{ng} / \mathrm{ml}$ on D0 $(P=0.96)$ and $1.67 \mathrm{ng} / \mathrm{ml}$ and $7.56 \mathrm{ng} / \mathrm{ml}$ on D4 ( $P=0.001)$, respectively. ROC curves for PCT fall and percentage change in PCT yielded AUC of 0.66 (95\% CI: 0.56-0.77) and 0.76 (95\% CI: 0.67-0.85) respectively. These values, however, are not statistically different from those in the entire group.

\section{Discussion}

In this prospective study of critically ill patients with severe sepsis/septic shock, we studied the prognostic significance of the change in procalcitonin level in 72-96 h. We found that a fall in procalcitonin level predicted survival; however, a change in SOFA score did the same as well. 
The most coommon primary diagnostic category was pneumonia, followed by severe acute pancreatitis and tropical illnesses (malaria, dengue, leptospirosis and others). The majority of infections were community acquired (63.2\%). In 242 adults with severe sepsis/septic shock from 24 ICUs in Finland, Karlsson et al. ${ }^{[10]}$ found higher procalcitonin levels in patients with community acquired infections as compared to those with nosocomial infections $(P=0.001)$. We did not find such an association.

A single value of procalcitonin, done at the time of admission, cannot predict the prognosis of the critically ill septic patient. This has been substantiated in several studies, ${ }^{[10-12]}$ as was also found in our study. The median procalcitonin level in our patients was $3.83 \mathrm{ng} / \mathrm{ml}$ at admission; $3.48 \mathrm{ng} / \mathrm{ml}$ among the survivors and $5.27 \mathrm{ng} / \mathrm{ml}$ among the NS $(P=0.48)$. In the study by Karlsson et al., ${ }^{[10]}$ procalcitonin level on the day of admission did not differ among survivors and NS $(P=0.64)$. In a prospective international multicenter study by Rau et al. conducted in 82 surgical patients with secondary peritonitis, ${ }^{[11]}$ procalcitonin level early in the course of illness predicted the presence of septic multiorgan failure and persistent sepsis, but was poorly correlated with death. Among 54 septic patients from a medical ICU in New Delhi, India, a procalcitonin level $\geq 7 \mathrm{ng} / \mathrm{ml}$ at admission predicted 28 days mortality with a hazard ratio of $2.6 ;^{[12]}$ however, this was not significant on multivariate analysis. Similarly, in 88 patients with septic shock admitted to an ICU of a tertiary care teaching hospital in Spain ${ }^{[13]}$ by Suberviola et al., the procalcitonin level at admission was $12.9 \mathrm{ng} / \mathrm{ml}$ and $13.5 \mathrm{ng} / \mathrm{ml}$ in survivors and NS respectively $(P=0.6)$.

The procalcitonin level is expected to fall with therapy; hence many studies looked at the value of procalcitonin at the end of $48-72 \mathrm{~h}$. In the study by Karlsson et al., ${ }^{[10]}$ the value after $72 \mathrm{~h}$ did not differ among survivors and NS $(P=0.99)$. In 28 patients with severe sepsis/ septic shock from Brazil, Azevedo et al. ${ }^{[14]}$ found that the procalcitonin level after $24-48 \mathrm{~h}$ was significantly different among survivors and NS (median $8.2 \mathrm{ng} / \mathrm{ml}$ vs. $68.6 \mathrm{ng} / \mathrm{ml}$ at $24 \mathrm{~h}$ and $4.6 \mathrm{ng} / \mathrm{ml}$ and $31 \mathrm{ng} / \mathrm{ml}$ at $48 \mathrm{~h}$ among survivors and NS respectively). Similar findings were obtained by Suberviola et al. ${ }^{[13]}$ with significantly different levels of procalcitonin $72 \mathrm{~h}$ after admission $(2.2 \mathrm{ng} / \mathrm{ml}$ vs. $20 \mathrm{ng} / \mathrm{ml}$ in survivors and NS respectively; $P<0.01$ ). This difference was, however, not significant on multivariate analysis. Seligman et al. ${ }^{[15]}$ found that the procalcitonin level on D4 showed a C-statistic of 0.86 to predict mortality and was the most accurate among C-reactive protein, midregional pro-atrial natriuretic peptide and copeptin, in 71 ICU patients with VAP. The number of patients in severe sepsis/septic shock was, however, small in this study $(28.4 \% / 4.4 \%$ respectively). In a study on 340 critically ill patients with suspected sepsis, the mean PCT level after $72 \mathrm{~h}$ was significantly lower in survivors $(0.61 \mathrm{ng} / \mathrm{ml})$ as compared to the admission value $(5.56 \mathrm{ng} / \mathrm{ml} ; P=0.0012)$; no such difference was seen in the NS. ${ }^{[16]}$ Convincing data could not be obtained for a single value of procalcitonin on D4 to be of great prognostic significance.

Most authors have attempted to correlate the change in procalcitonin level at 48-72 $\mathrm{h}$ after starting therapy, with outcome. In our study, the procalcitonin level decreased to $1.48 \mathrm{ng} / \mathrm{ml}$ after $72-96 \mathrm{~h}$; the level fell to $0.98 \mathrm{ng} / \mathrm{ml}$ in the survivors, but remained almost same at $6.09 \mathrm{ng} / \mathrm{ml}$ in the NS. Karlsson et al..$^{[10]}$ found that a substantial decrease in the procalcitonin level at $72 \mathrm{~h}(>50 \%$ decrease) was associated with a lower hospital mortality $(12.2 \%)$ as compared to those with $<50 \%$ decrease $(29.8 \%$, $P=0.007)$; however this was not an independent predictor of mortality. In a pilot study of procalcitonin clearance (decrease in value as a percentage of value at admission) among 27 critically ill ICU patients with septic shock and multiorgan dysfunction, ${ }^{[17]}$ the clearance at $24 \mathrm{~h}$ and $48 \mathrm{~h}$ had AUC of 0.74 and 0.86 respectively to predict survival. Similarly, in 28 patients with severe sepsis/septic shock, Azevedo et al. ${ }^{[14]}$ found procalcitonin clearance at $24 \mathrm{~h}$ was significantly higher among survivors as compared to NS $(P=0.028)$. Suberviola et al. ${ }^{[13]}$ found that a decreasing value of procalcitonin (over $72 \mathrm{~h}$ ) among 88 patients with septic shock was an independent predictor of survival (odds ratio 0.1 ); procalcitonin clearance of $70 \%$ differentiated survivors from NS with a sensitivity of $94.7 \%$ and a specificity of $53 \%$. Seligman et al., ${ }^{[18]}$ in 75 ICU patients with VAP, found that a fall in procalcitonin in 4 days predicts survival with an odds ratio of 4.43 (95\% CIs: $1.08-18.18 ; P=0.04)$. In a study of 180 septic patients from a medical ICU in France, ${ }^{[19]}$ fall in procalcitonin level between D2 and D3 after onset of sepsis was found to be an independent predictor of survival (odds ratio: 2.94; 95\% CI: 1.22-7.09). Among 64 postoperative ICU patients with severe sepsis/septic shock, Tschaikowsky et al.$^{[20]}$ showed that a fall in procalcitonin level to $\leq 50 \%$ of the baseline was an independent predictor of survival; the sensitivity was good (97\%), but the specificity was only $35 \%$. Li et al., in a recent study on 102 septic patients from an ICU in China, ${ }^{[21]}$ showed that the level of PCT decreased in survivors from D1 to D3 and D5 while there was no change in the level in NS $(P<0.05)$. In a small study on 37 patients with septic shock, dynamic changes in PCT and SOFA score were found to be 
useful indicators of survival. ${ }^{[22]}$ PCT level decreased by a median of $9.73 \mathrm{ng} / \mathrm{ml}$ in survivors but increased by $5.95 \mathrm{ng} / \mathrm{ml}$ in NS. In contrast to the studies till date, in our study, the change in procalcitonin was different in survivors and NS with fall in the median value in survivors and no change in NS. The median value of percentage fall of procalcitonin was $73.5 \%$ in survivors as against $24.4 \%$ in NS. $50 \%$ fall in procalcitonin level was $68 \%$ sensitive and $64 \%$ specific while $70 \%$ fall yielded a sensitivity of $47 \%$ with a specificity of $93 \%$. Looking at the absolute change in procalcitonin, a fall in procalcitonin $>1 \mathrm{ng} / \mathrm{ml}$ identified survivors with a C-statistic of 0.78 . Repeating the analysis excluding patients with a low level of procalcitonin on both days $(\leq 1 \mathrm{ng} / \mathrm{ml})$ increases the AUC, but this increase was not significant statistically.

Another important finding is that SOFA score fared equally well as far as prediction of prognosis is concerned. The AUC for percentage change in procalcitonin level was 0.73 while that for a change in SOFA score was 0.78 . Similar findings have been found in a few other studies. ${ }^{[21,22]}$

Our study has some limitations. Firstly, many patients present late to us after being managed in other ICUs and hence the time of the first procalcitonin estimation is not necessarily the $1^{\text {st }}$ day of severe sepsis or septic shock. Further, the day of illness was not noted during data collection. Secondly, many patients died before the second sample could be taken; hence our hypothesis could not be tested in all the patients. The procalcitonin estimation method used here had an upper limit of $100 \mathrm{ng} / \mathrm{ml}$ and hence, actual levels above this do not find representation. Many patients have a prolonged stay in our ICU; the final outcome may not be related to the episode of sepsis for which the patient was admitted.

Based on this study, we recommend that an estimation of procalcitonin at admission, followed by estimation within the next 72-96 h could aid the prognostic assessment of critically ill patients with severe sepsis/ septic shock, along with SOFA scores calculated on the same days. A rise or no change in procalcitonin level should alert the clinician to inadequacy of therapy.

To conclude, in a group of critically ill patients with severe sepsis/septic shock, a fall in procalcitonin level is associated with a favorable prognosis. Change in SOFA score performs equally well in this group of patients in predicting prognosis.

\section{Acknowledgments}

We acknowledge the help in data collection by Dr. Arun Sharma, Dr. Sukhen Samanta and Dr. Tanmoy Ghatak.

\section{References}

1. Kibe S, Adams K, Barlow G. Diagnostic and prognostic biomarkers of sepsis in critical care. J Antimicrob Chemother 2011;66 Suppl 2:ii33-40.

2. Tang BM, Eslick GD, Craig JC, McLean AS. Accuracy of procalcitonin for sepsis diagnosis in critically ill patients: Systematic review and meta-analysis. Lancet Infect Dis 2007;7:210-7.

3. Wacker C, Prkno A, Brunkhorst FM, Schlattmann P. Procalcitonin as a diagnostic marker for sepsis: A systematic review and meta-analysis. Lancet Infect Dis 2013;13:426-35.

4. Bouadma L, Luyt CE, Tubach F, Craceo C, Alvarez A, Schwebel C, et al. Use of procalcitonin to reduce patients' exposure to antibiotics in intensive care units (PRORATA trial): A multicentre randomised controlled trial. Lancet 2010;375:463-74.

5. Agarwal R, Schwartz DN. Procalcitonin to guide duration of antimicrobial therapy in intensive care units: A systematic review. Clin Infect Dis 2011;53:379-87.

6. Schuetz P, Müller B, Christ-Crain M, Stolz D, Tamm M, Bouadma L, et al. Procalcitonin to initiate or discontinue antibioties in acute respiratory tract infections. Cochrane Database Syst Rev 2012;9:CD007498.

7. Krüger S, Ewig S, Marre R, Papassotiriou J, Richter K, von Baum H, et al. Procalcitonin predicts patients at low risk of death from community-acquired pneumonia across all CRB-65 classes. Eur Respir J 2008;31:349-55.

8. Andrijevic I, Matijasevic J, Andrijevic L, Kovacevic T, Zaric B. Interleukin- 6 and procalcitonin as biomarkers in mortality prediction of hospitalized patients with community acquired pneumonia. Ann Thorac Med 2014;9:162-7.

9. Bone RC, Balk RA, Cerra FB, Dellinger RP, Fein AM, Knaus WA, et al. Definitions for sepsis and organ failure and guidelines for the use of innovative therapies in sepsis. The ACCP/SCCM Consensus Conference Committee. American College of Chest Physicians/Society of Critical Care Medicine. Chest 1992;101:1644-55.

10. Karlsson S, Heikkinen M, Pettilä V, Alila S, Väisänen S, Pulkki K, et al. Predictive value of procalcitonin decrease in patients with severe sepsis: A prospective observational study. Crit Care 2010;14:R205.

11. Rau BM, Frigerio I, Büchler MW, Wegscheider K, Bassi C, Puolakkainen PA, et al. Evaluation of procalcitonin for predicting septic multiorgan failure and overall prognosis in secondary peritonitis: A prospective, international multicenter study. Arch Surg 2007;142:134-42.

12. Jain S, Sinha S, Sharma SK, Samantaray JC, Aggrawal P, Vikram NK, et al. Procalcitonin as a prognostic marker for sepsis: A prospective observational study. BMC Res Notes 2014;7:458.

13. Suberviola B, Castellanos-Ortega A, González-Castro A, García-Astudillo LA, Fernández-Miret B. Prognostic value of procalcitonin, C-reactive protein and leukocytes in septic shock. Med Intensiva 2012;36:177-84.

14. Azevedo JR, Torres OJ, Czeczko NG, Tuon FF, Nassif PA, Souza GD. Procalcitonin as a prognostic biomarker of severe sepsis and septic shock. Rev Col Bras Cir 2012;39:456-61.

15. Seligman R, Seligman BG, Teixeira PJ. Comparing the accuracy of predictors of mortality in ventilator-associated pneumonia. J Bras Pneumol 2011;37:495-503.

16. Hur M, Kim H, Lee S, Cristofano F, Magrini L, Marino R, et al. Diagnostic and prognostic utilities of multimarkers approach using procalcitonin, B-type natriuretic peptide, and neutrophil gelatinase-associated lipocalin in critically ill patients with suspected sepsis. BMC Infect Dis 2014;14:224.

17. Ruiz-Rodríguez JC, Caballero J, Ruiz-Sanmartin A, Ribas VJ, Pérez M, Bóveda JL, et al. Usefulness of procalcitonin clearance as a prognostic biomarker in septic shock. A prospective pilot study. Med Intensiva 2012;36:475-80. 
18. Seligman R, Meisner M, Lisboa TC, Hertz FT, Filippin TB, Fachel JM, et al. Decreases in procalcitonin and C-reactive protein are strong predictors of survival in ventilator-associated pneumonia. Crit Care 2006;10:R125.

19. Charles PE, Tinel C, Barbar S, Aho S, Prin S, Doise JM, et al. Procalcitonin kinetics within the first days of sepsis: Relationship with the appropriateness of antibiotic therapy and the outcome. Crit Care 2009; 13 :R38.

20. Tschaikowsky K, Hedwig-Geissing M, Braun GG, Radespiel-Troeger M. Predictive value of procalcitonin, interleukin-6, and C-reactive protein for survival in postoperative patients with severe sepsis. J Crit Care 2011;26:54-64.

21. Li Z, Wang H, Liu J, Chen B, Li G. Serum soluble triggering receptor expressed on myeloid cells-1 and procalcitonin can reflect sepsis severity and predict prognosis: A prospective cohort study. Mediators Inflamm 2014;2014:641039.

22. Guan J, Lin Z, Lue H. Dynamic change of procalcitonin, rather than concentration itself, is predictive of survival in septic shock patients when beyond $10 \mathrm{ng} / \mathrm{mL}$. Shock 2011;36:570-4.

How to cite this article: Poddar B, Gurjar M, Singh S, Aggarwal A, Singh R, Azim A, et al. Procalcitonin kinetics as a prognostic marker in severe sepsis/septic shock. Indian J Crit Care Med 2015;19:140-6.

Source of Support: The study was funded by a grant to BP from the host Institute. Conflict of Interest: None declared.

\section{Author Help: Online submission of the manuscripts}

Articles can be submitted online from http://www.journalonweb.com. For online submission, the articles should be prepared in two files (first page file and article file). Images should be submitted separately.

1) First Page File:

Prepare the title page, covering letter, acknowledgement etc. using a word processor program. All information related to your identity should be included here. Use text/rtf/doc/pdf files. Do not zip the files.

2) Article File:

The main text of the article, beginning with the Abstract to References (including tables) should be in this file. Do not include any information (such as acknowledgement, your names in page headers etc.) in this file. Use text/rtt/doc/pdf files. Do not zip the files. Limit the file size to $1 \mathrm{MB}$. Do not incorporate images in the file. If file size is large, graphs can be submitted separately as images, without their being incorporated in the article file. This will reduce the size of the file.

3) Images:

Submit good quality color images. Each image should be less than $4096 \mathrm{~kb}(4 \mathrm{MB})$ in size. The size of the image can be reduced by decreasing the actual height and width of the images (keep up to about 6 inches and up to about $1800 \times 1200$ pixels). JPEG is the most suitable file format. The image quality should be good enough to judge the scientific value of the image. For the purpose of printing, always retain a good quality, high resolution image. This high resolution image should be sent to the editorial office at the time of sending a revised article.

4) Legends:

Legends for the figures/images should be included at the end of the article file. 